LETTER TO JMG

\title{
A locus for autosomal dominant keratoconus maps to human chromosome 3pl4-q13
}

\author{
F Brancati, E M Valente, A Sarkozy, J Fehèr, M Castori, P Del Duca, R Mingarelli, A Pizzuti, \\ B Dallapiccola
}

J Med Genet 2004;41:188-192. doi: 10.1136/jmg.2003.012872

$\mathrm{K}$ eratoconus (OMIMI48300) is a bilateral, non-inflammatory, slowly progressive, corneal ectasia that is a major cause of corneal transplant. Characteristically, the cornea becomes thin and conical, with myopia and irregular astigmatism that leads to vision impairment. The incidence of keratoconus is between 50 and 230 per 100 000, with remarkable differences between ethnic groups. ${ }^{1}$ Although the pathogenesis of keratoconus still is unknown, little doubt exists about an underlying genetic background. A positive family history is found in $6-8 \%$ of patients with keratoconus, and concordance is high among monozygotic twins. ${ }^{12}$ In rare instances, keratoconus is inherited either as a mendelian trait or is associated with a genetic disorder (for example, Down syndrome, Leber's amaurosis, or connective tissue diseases). For most patients, however, the disease is sporadic. $^{3}$ The lack of multiple familial cases is a major obstacle to linkage analysis. To date, three loci have been associated with keratoconus, none of them through a genomewide search in a single informative family. A putative $6.8 \mathrm{cM}$ locus was identified in a family affected by keratoconus by direct scan of chromosome 21 only, while an association at $20 \mathrm{q} 12$ was found in seven related Tasmanian patients. ${ }^{45}$ More recently, a non-parametric linkage analysis in 20 Finnish small pedigrees with autosomal dominant keratoconus identified a third locus to chromosome 16q. ${ }^{6}$ Finally, two distinct heterozygous mutations in the VSXI homeobox gene were identified with a candidate gene approach in two families affected by keratoconus.

Recent advances in computerised topographic diagnostic techniques enable higher accuracy in the diagnosis of keratoconus, including forme fruste, which eases the identification of extensive families affected by keratoconus. We describe an Italian family with autosomal dominant pure keratoconus and the localisation of a novel keratoconus locus to chromosome 3pl4-q13.

\section{METHODS}

\section{Clinical studies}

We identified an Italian pedigree with autosomal dominant keratoconus spanning two generations. Fourteen family members underwent ophthalmological and slit lamp examination, and all but one (II:9) had corneal topography (Keratron; Opticon 2000, Rome, Italy). A diagnosis of definite keratoconus was established when central or paracentral corneal thinning or conical protrusion of the cornea with or without stromal scar tissue, or both, was found, in association with a videokeratographic picture typical of keratoconus. Patients who previously had undergone penetrating corneal transplant also received a diagnosis of definite keratoconus. A diagnosis of latent or forme fruste keratoconus was established when no signs of keratoconus were found on slit lamp examination but when corneal topography showed abnormal findings, such as central steepening, inferior-superior

\section{Key points}

- An Italian pedigree with 11 members in two generations with autosomal dominant keratoconus (OMIM 148300) was investigated.

- Linkage to all known keratoconus loci on chromosomes 16,20 , and 21 was excluded. A genomewide search allowed mapping of a novel keratoconus locus to chromosome 3p14-q13, with a maximum logarithm of odds score of 3.09. Analysis of key recombinant members placed the keratoconus locus to a $43.7 \mathrm{cM}$ region flanked by markers D3S1600 and D3S1278. This spans about $53 \mathrm{Mb}$ on the physical map and includes about $4.5 \mathrm{Mb}$ centromeric DNA.

- Mutation analysis of COL8A1, an interesting candidate gene located within the linked region, did not show any pathogenic mutations.

- This is the first locus for autosomal dominant pure keratoconus identified by means of a genomewide search performed in a single informative family.

asymmetry, differences between right and left central corneal power, and skewing of the steepest radial axes above and below the horizontal meridian. ${ }^{8}$

\section{Linkage analysis}

After informed consent, 15 family members and six spouses were blood sampled. Genomic DNA was extracted with standard procedures. Linkage of the disease with known keratoconus loci was excluded by genotyping microsatellite markers that spanned chromosome 21, 20q12, 16q, and 20pll-qll loci. For the genomewide search, 380 markers that covered the 22 autosomes with an average distance of $10 \mathrm{cM}$ were amplified by polymerase chain reaction in a Perkin Elmer 9700 thermal cycler (Perkin Elmer, Wellesley, MA, USA) with panels of fluorescently labelled primers (ABI Prism Linkage Mapping Set version 2; Applied Biosystems, Foster City, CA, USA). Polymerase chain reactions were performed in microtitre plates in a final volume of $10 \mu \mathrm{l}$ containing $50 \mathrm{ng}$ genomic DNA, 5 pmol of each primer, $2 \mathrm{mM}$ each of dATP, dCTP, dGTP, and dTTP, $1 \mu$ l GeneAmp $10 \times$ magnesium free PCR Gold buffer (Applied Biosystems, Foster City, CA, USA), $2.5 \mathrm{mM}$ magnesium chloride, and 0.5 units AmpliTaq Gold DNA polymerase (Applied Biosystems, Foster City, CA). Polymerase chain reaction conditions for these markers already have been optimised by the manufacturers, and all markers could be amplified under the same conditions. Reaction mixes were first heated to $95^{\circ} \mathrm{C}$ for 11 minutes; subsequent cycling conditions were $94^{\circ} \mathrm{C}$ for 
15 seconds, $55^{\circ} \mathrm{C}$ for 15 seconds, and $72^{\circ} \mathrm{C}$ for 30 seconds (repeated for 10 cycles); $89^{\circ} \mathrm{C}$ for 15 seconds, $55^{\circ} \mathrm{C}$ for 15 seconds, and $72^{\circ} \mathrm{C}$ for 30 seconds (repeated for 20 cycles); and a final extension of $72^{\circ} \mathrm{C}$ for 10 minutes. After amplification, PCR products from each panel were pooled in a tube with Genescan 500HD size standard (Applied Biosystems, Foster City, CA, USA) and loaded on a 3100 automated DNA sequencer (Applied Biosystems, Foster City, CA, USA). Analysis of the amplified fragments was performed with Genescan and Genotyper software (Applied Biosystems, Foster City, CA, USA). Two point logarithm of odds (LOD) scores were generated with the Fastlink version of the Mlink program; ${ }^{9}$ we assumed an equal man-woman recombination rate, autosomal dominant inheritance, a gene frequency of 0.0001 , and reduced penetrance $(0.80)$. Allele frequencies were estimated based on a random sample of 16 chromosomes (12 from the six healthy spouses and four from the two people in generation I). Multipoint LOD scores were obtained with Simwalk2 software. ${ }^{10}$

We constructed haplotypes manually and assigned phase on the basis of the smallest number of recombinants. To saturate the linked region, we selected five novel polymorphic markers from the Human Genome Working Draft with Tandem Repeat Finder software. ${ }^{11}$ We took genetic distances between markers from the Marshfield genetic map (www.marshfieldclinic.org/research/genetics/default.htm), while physical distances were taken from the University of California Santa Cruz draft of the human genome (www.genome.ucsc.edu) (table 1). Polymerase chain reactions were prepared in a volume of $10 \mu \mathrm{l}$ as described above. After heating for 11 minutes at $95^{\circ} \mathrm{C}$, subsequent cycling conditions were $94^{\circ} \mathrm{C}$ for 30 seconds, $52-60^{\circ} \mathrm{C}$ for 30 seconds, and $72^{\circ} \mathrm{C}$ for 30 seconds (repeated for 28-33 cycles). We optimised the annealing temperature and number of cycles to produce an approximately constant PCR yield. Primer pairs and PCR conditions for these markers are available on request.

\section{Candidate gene analysis}

The five exons of the alphal type VIII collagen (COL8AI; RefSeq NM_001850) were amplified from genomic DNA under the following conditions. For PCR, $250 \mathrm{ng}$ of genomic DNA was used as a template with $10 \times$ PCR buffer, $2.5 \mathrm{mM}$ magnesium chloride, $10 \mathrm{mM}$ of nucleotides (dNTP), $50 \mathrm{pmol}$ of each primer, and 1.25 units of Taq Promega Polymerase (Promega, Madison, WI, USA) in a total volume of $50 \mu \mathrm{l}$. Primer pairs are available on request. The coding regions and exon-intron boundaries were analysed by direct sequencing of purified PCR products with an ABI BigDye terminator Sequencing Kit and ABI 3100 Capillary Array Sequencer (Applied Biosystem, Foster City, CA). Sequences were

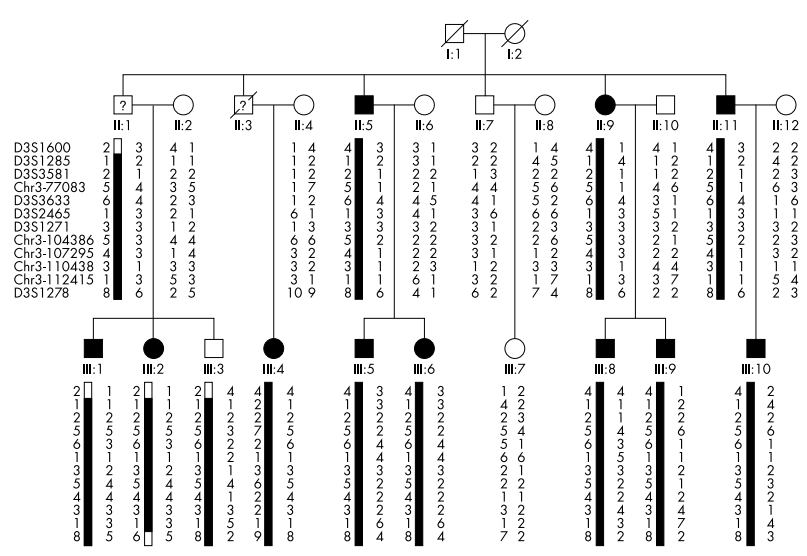

Figure 1 Pedigree of family and haplotypes of markers spanning the novel keratoconus locus. affected man; $\square$ unaffected man; affected woman; $\bigcirc$ unaffected woman; / deceased; ? unknown phenotype; I haplotype that segregated with disease in the family.

analysed with Sequencing Analysis and SeqScape software (Applied Biosystem, Foster City, CA, USA).

\section{RESULTS}

\section{Clinical examination}

The mode of inheritance was autosomal dominant, with male to male transmission. Seven people received a diagnosis of definite keratoconus, while four were diagnosed with forme fruste keratoconus. A simplified family tree is presented in fig 1 ; table 2 summarises the clinical features of the 11 affected family members.

Individual III:6 underwent bilateral corneal transplant at age 30 years for advanced keratoconus. She had complained of progressive visual loss since the age of 18 years, with photophobia and excessive tearing. In six people (II:5, II:9, II:11, III:1, III:5, and III:8), a diagnosis of keratoconus was established on clinical and slit lamp examination. Videokeratography was subsequently performed in all but individual II:9 and confirmed the diagnosis (fig 2). All these patients presented with photophobia or excessive tearing, sometimes associated with vision impairment, except individual II:5, who did not have any ocular symptoms. The age at onset varied among affected individuals, ranging from 18 to 42 years (table 2 ). Patient II:5 complained of visus reduction that could be corrected with lenses, but could not report the age of onset. Four individuals received a diagnosis of forme fruste keratoconus on the basis of videokeratography (III:2, III:4, III:9, and III:10) (fig 2). One of them (III:2) reported mild photophobia. Individual II:1 was not available for slit

Table 1 Pairwise LOD scores between keratoconus and markers on chromosome 3p14-q13

\begin{tabular}{|c|c|c|c|c|c|c|c|c|c|}
\hline \multirow[b]{2}{*}{ Markers } & \multicolumn{2}{|c|}{ Position of microsatellite marker } & \multicolumn{7}{|c|}{ LOD scores at $\theta=$} \\
\hline & On genetic map (CM) & On physical map (Mb) & 0.0 & 0.01 & 0.05 & 0.1 & 0.2 & 0.3 & 0.4 \\
\hline D3S1600 & 85.97 & 62.184 & -0.51 & 0.77 & 1.30 & 1.39 & 1.19 & 0.78 & 0.28 \\
\hline D3S 1285 & 91.18 & 63.816 & 2.61 & 2.57 & 2.41 & 2.19 & 1.67 & 1.05 & 0.38 \\
\hline D3S3581 & 104.83 & 72.604 & 2.73 & 2.69 & 2.53 & 2.29 & 1.75 & 1.10 & 0.39 \\
\hline Chr3-77083 & NA & 77.083 & 3.09 & 3.04 & 2.86 & 2.60 & 2.00 & 1.28 & 0.48 \\
\hline D3S3633 & 108.48 & 79.653 & 3.07 & 3.03 & 2.84 & 2.58 & 1.98 & 1.27 & 0.47 \\
\hline D3S2465 & 111.89 & 82.276 & 3.03 & 2.98 & 2.80 & 2.54 & 1.94 & 1.24 & 0.46 \\
\hline D3S1271 & 117.76 & 97.405 & 1.02 & 1.00 & 0.90 & 0.78 & 0.53 & 0.29 & 0.09 \\
\hline Chr3-104386 & NA & 104.386 & 3.00 & 2.95 & 2.77 & 2.51 & 1.91 & 1.20 & 0.42 \\
\hline Chr3-107295 & NA & 107.295 & 2.89 & 2.85 & 2.66 & 2.40 & 1.80 & 1.09 & 0.35 \\
\hline Chr3-110438 & NA & 110.438 & 2.76 & 2.72 & 2.55 & 2.31 & 1.77 & 1.12 & 0.41 \\
\hline Chr3-112415 & NA & 112.415 & 1.88 & 1.85 & 1.73 & 1.55 & 1.14 & 0.66 & 0.19 \\
\hline D3S 1278 & 129.73 & 116.405 & -1.45 & 1.04 & 1.57 & 1.63 & 1.38 & 0.91 & 0.32 \\
\hline
\end{tabular}




\begin{tabular}{|c|c|c|c|c|c|c|c|}
\hline \multirow[b]{2}{*}{ Patient } & \multirow[b]{2}{*}{$\begin{array}{l}\text { Age } \\
\text { (years) }\end{array}$} & \multirow[b]{2}{*}{ Sex } & \multicolumn{2}{|l|}{ Ocular symptoms } & \multirow[b]{2}{*}{$\begin{array}{l}\text { Slit lamp } \\
\text { examination }\end{array}$} & \multirow[b]{2}{*}{$\begin{array}{l}\text { Video- } \\
\text { keratography }\end{array}$} & \multirow[b]{2}{*}{ Diagnosis } \\
\hline & & & Symptom & $\begin{array}{l}\text { Age at } \\
\text { onset } \\
\text { (years) }\end{array}$ & & & \\
\hline II:5 & 70 & Man & $\begin{array}{l}\text { Good vision } \\
\text { with lenses }\end{array}$ & NK & Gerontoxon & + & Keratoconus \\
\hline 11:9 & 66 & Woman & $\begin{array}{l}\text { Tearing, vision } \\
\text { impairment }\end{array}$ & 42 & $\begin{array}{l}\text { Central or } \\
\text { paracentral } \\
\text { corneal scar }\end{array}$ & Not examined & Keratoconus \\
\hline II:11 & 64 & Man & $\begin{array}{l}\text { Photophobia, } \\
\text { vision impairment }\end{array}$ & 38 & $\begin{array}{l}\text { Hudson-Stahli's } \\
\text { line }\end{array}$ & + & Keratoconus \\
\hline III:1 & 44 & Man & $\begin{array}{l}\text { Photophobia, } \\
\text { vision impairment }\end{array}$ & 22 & $\begin{array}{l}\text { Displaced corneal } \\
\text { apex }\end{array}$ & + & Keratoconus \\
\hline III:2 & 46 & Woman & Mild photophobia & 35 & $\begin{array}{l}\text { Hyperaemia, } \\
\text { visible corneal } \\
\text { nerves }\end{array}$ & $\begin{array}{l}\text { Superior-inferior } \\
\text { asymmetry }\end{array}$ & $\begin{array}{l}\text { Forme fruste } \\
\text { keratoconus }\end{array}$ \\
\hline III:4 & 46 & Woman & None & & Normal cornea & $\begin{array}{l}\text { Superior-inferior } \\
\text { asymmetry }\end{array}$ & $\begin{array}{l}\text { Forme fruste } \\
\text { keratoconus }\end{array}$ \\
\hline III:5 & 38 & Man & $\begin{array}{l}\text { Photophobia, } \\
\text { tearing }\end{array}$ & 30 & $\begin{array}{l}\text { Hudson-Stahli's } \\
\text { line }\end{array}$ & + & Keratoconus \\
\hline III: 6 & 45 & Woman & $\begin{array}{l}\text { Corneal transplant } \\
\text { at } 30 \text { years }\end{array}$ & 18 & Not examined & Clear transplant & Keratoconus \\
\hline III:8 & 40 & Man & $\begin{array}{l}\text { Photophobia, } \\
\text { tearing, poor } \\
\text { vision }\end{array}$ & 21 & $\begin{array}{l}\text { Paracentral corneal } \\
\text { scar }\end{array}$ & + & Keratoconus \\
\hline III:9 & 42 & Man & None & & Normal cornea & $\begin{array}{l}\text { High difference in } \\
\text { astigmatism } \\
\text { between left and } \\
\text { right eyes }\end{array}$ & $\begin{array}{l}\text { Forme fruste } \\
\text { keratoconus }\end{array}$ \\
\hline III:10 & 26 & Man & None & & Normal cornea & $\begin{array}{l}\text { Superior-inferior } \\
\text { asymmetry }\end{array}$ & $\begin{array}{l}\text { Forme fruste } \\
\text { keratoconus }\end{array}$ \\
\hline
\end{tabular}

lamp examination or videokeratography examination. His clinical history was characterised by very mild ocular symptoms (that is, mild photophobia) since the age of 60 years, but he could not be examined, as he was in a wheelchair because of limb girdle muscular dystrophy. This man was considered as "unknown phenotype" for linkage purposes. Three family members (II:7, III:3, and III:7) did not complain of any ocular symptom, and all ophthalmologic examinations were normal (fig 2).

\section{Linkage and molecular genetic analysis}

Linkage to known keratoconus loci (on chromosomes 21, 20q12, and 16q) and to the VSXI gene on 20pll-qll was excluded (data not shown). The genomewide search produced negative or non-significant LOD scores for all but 13 microsatellite markers on chromosomes 1, 2, 3, 6, 7, 11, and 13. The regions that surrounded these loci and regions that surrounded non-informative markers were saturated with more markers, and haplotypes were manually constructed. The segregation of different haplotypes in affected individuals and the negative LOD scores obtained allowed exclusion of all loci except the pericentromeric region of chromosome 3, in which a common haplotype was shared by the 11 affected family members. The upper and lower boundaries were determined by recombination events in individuals II: 1 and III:2, which identified a $43.7 \mathrm{cM}$ linked region flanked by markers D3S1600 and D3S1278. this region spanned about $53 \mathrm{Mb}$ and included about $4.5 \mathrm{Mb}$ of centromeric DNA. All genotyped markers in the region generated positive LOD scores, with a maximum value of 3.09 for marker Chr3:77.08 $(\theta=0$; penetrance $=0.80)$. Logarithm of odds scores and intermarker distances are shown in table 1; fig 3 shows the multipoint graph.

In silico analysis of the linked region identified more than 100 genes. An interesting candidate gene was COL8Al, which codes for the human alphal(VIII) chain of type VIII collagen, highly expressed in the cornea. Sequencing of the whole
COL8A1 coding region and exon-intron boundaries did not show any pathogenic mutation. A single nucleotide, $G$ to $T$ substitution, not previously described, was found at position -59 in the untranslated exon 3 of the gene. Nine affected people and three spouses (II:4, II:8, and II:10) were heterozygous for the $\mathrm{G}$ to $\mathrm{T}$ change, but individuals III:4 and III:9 were homozygous. This substitution therefore was considered as a polymorphic variant.

\section{DISCUSSION}

We report a clinical and molecular investigation of a large central Italian kindred affected by pure keratoconus and the mapping of a novel keratoconus locus to the pericentromeric region of chromosome 3

The phenotype mainly was characterised by slowly progressive visual impairment and ocular symptoms, such as photophobia and tearing. The age of onset, clinical presentation, and disease progression varied widely among the 11 affected family members (table 2). For instance, individual III:6 underwent corneal transplant because of severe keratoconus at age 30 years, while patient III:4 was still asymptomatic at age 46 and received a diagnosis of forme fruste keratoconus on videokeratography. A true lack of penetrance was also observed, as individual III:3, aged 39 years, shared the disease haplotype but the diagnosis of keratoconus was excluded by slit lamp examination and videokeratography.

Reduced penetrance and variable expression of autosomal dominant keratoconus have been reported in several pedigrees. $^{4-7} 12$ However, it must be noted that the detection rate for keratoconus depends strictly on the sensitivity of the diagnostic techniques used. ${ }^{13}$ In this family, 10 patients were evaluated by both slit lamp examination and videokeratography: four $(40 \%)$ received a diagnosis of forme fruste keratoconus only by videokeratography, while slit lamp examination was normal. These data confirm that abortive 

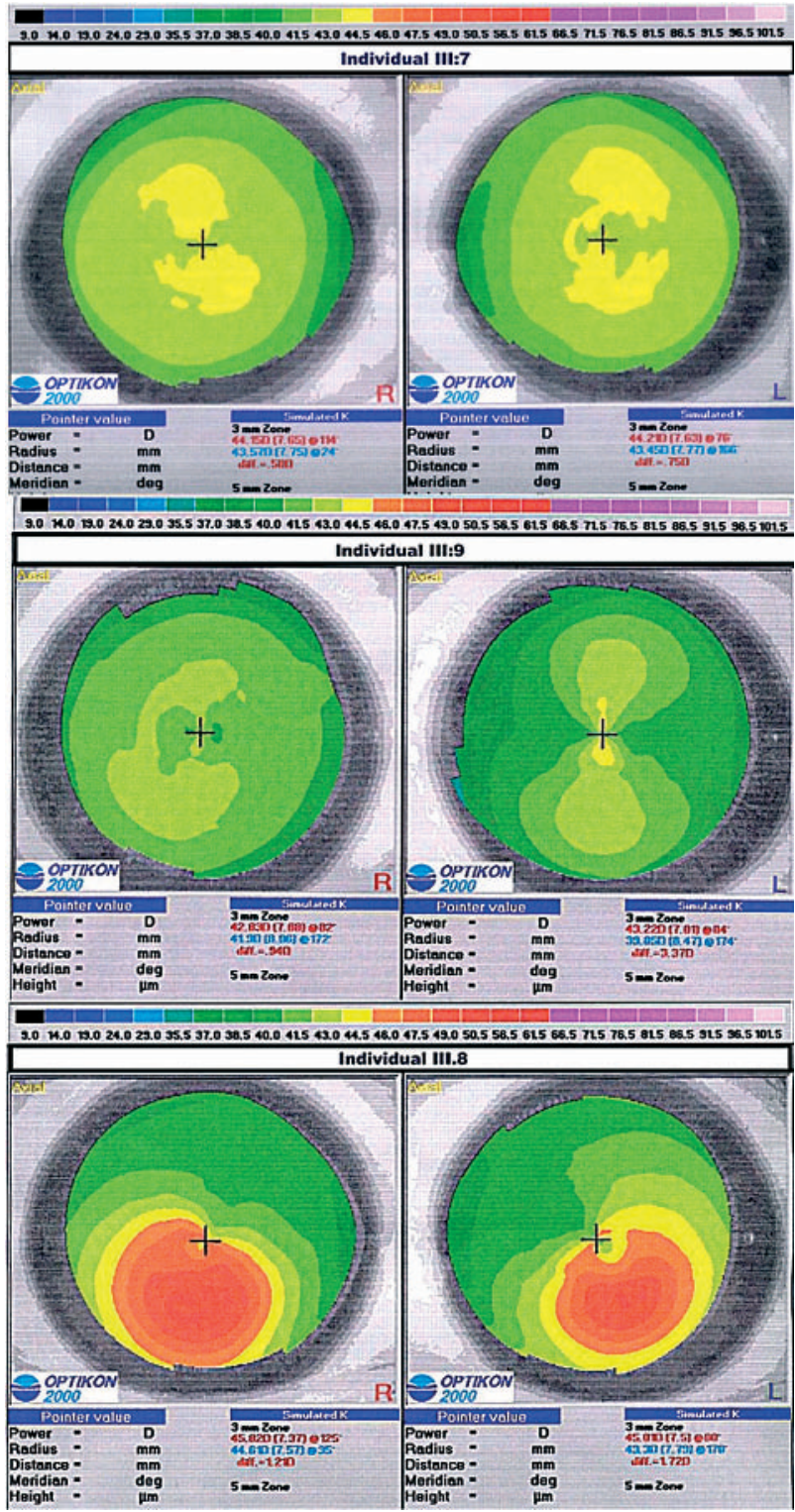

Figure 2 Videokeratography showing: normal corneal presentation in individual III:7 (top panel), forme fruste keratoconus in patient III:9 (middle panel); and keratoconus in patient III:8 (bottom panel).

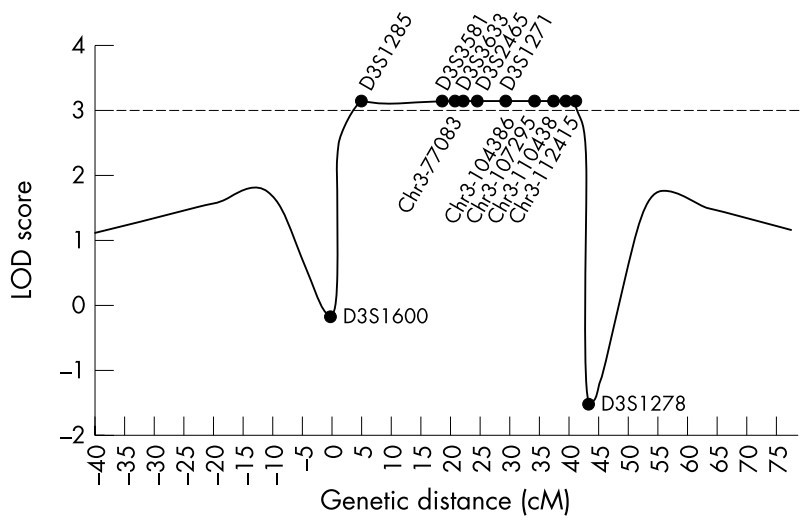

Figure 3 Multipoint LOD scores between the disease and markers on chromosome 3pl4-q13. forms of keratoconus are common and can be missed without a thorough examination.

The high rate of forme fruste keratoconus, as well as the incomplete penetrance, can partly explain the paucity of large keratoconus kindred in the literature. In fact, although a number of putative keratoconus loci have been identified so far, ${ }^{1-6}$ this is the first locus mapped by a genomewide search in a single informative family.

We obtained a maximum two point LOD score of 3.09 for marker Chr3-77083 (at $\theta=0$ ), while multipoint linkage analysis generated an LOD score $>3.00$ in a $43.7 \mathrm{cM}$ interval between markers D3S1600 and D3S1278. Although these LOD scores represent only tentative evidence of linkage, a common haplotype shared by all keratoconus family members was observed only in this region, while the rest of the genome was excluded thoroughly by linkage and haplotype analyses. The gene frequency of autosomal dominant keratoconus is not known, but families with clear mendelian inheritance are much rarer than sporadic cases, which have an incidence of approximately 1 per 2000 in the general population. ${ }^{1}$ For this reason, a gene frequency of 1 in 10000 was assumed for linkage calculation in this family.

An interesting gene within the mapped region is COL8AI, which encodes for the human alphal(VIII) chain of type VIII collagen. A number of collagen genes (that is, collagen types I and III-VIII) have been considered excellent candidates for keratoconus on the basis of their expression pattern in different layers of the cornea. ${ }^{1}$ In particular, studies of the Descemet's membrane have shown that type VIII collagen is a major component of the hexagonal lattice of this tissue..$^{13}$ Recently, missense mutations in COL8A2, which encodes the alpha2 chain of type VIII collagen, have been identified in two forms of corneal endothelial dystrophy, underlining its role in influencing the terminal differentiation of corneal endothelial cells. ${ }^{15}$ We could not detect any pathogenic mutations in the coding sequences and exon-intron boundaries of COL8A1. As collagen VIII is known to exist in vivo as heterotrimers or homotrimers, deletions of the entire gene are unlikely to play a pathogenic role in keratoconus. Intronic and regulative regions of the COL8AI gene were not analysed, however, so the occurrence of aberrant splicing or expression could not be ruled out.

The identification of additional autosomal dominant families linked to this locus will help evaluate its role among familial keratoconus, refine the linked region, and ease the identification of positional candidate genes.

\section{Authors' affiliations}

F Brancati, E M Valente, A Sarkozy, M Castori, R Mingarelli, A Pizzuti, B Dallapiccola, CSS Hospital, IRCCS, San Giovanni Rotondo and CSSMendel Institute, Rome, Italy

F Brancati, A Sarkozy, M Castori, A Pizzuti, B Dallapiccola, Department of Experimental Medicine and Pathology, University "La Sapienza," Rome, Italy

J Fehèr, Department of Ophthalmology, University "La Sapienza," Rome, Italy

P Del Duca, UO Internal Medicine, POC, Montefiascone, Viterbo, Italy

Funding: This work was supported by grants from the Italian Ministry of Health, "Ricerca Corrente 2003" and the Italian Ministry of Education, University and Research, "Progetto Facoltà 2002".

Conflicts of interest: None declared.

Correspondence to: Dr A Pizzuti, CSS. Mendel Institute, Viale Regina Margherita 261, I-00198 Rome, Italy; a.pizzuti@css-mendel.it

\section{REFERENCES}

1 Rabinowitz YS. Keratoconus. Surv Ophthalmol 1998;42:297-319.

2 Parker J, Ko WW, Pavlopoulos G, Wolfe PJ, Rabinowitz YS, Feldman ST.

Videokeratography of keratoconus in monozygotic twins. J Refract Surg 1996;12:180-3. 
3 Edwards M, McGhee CN, Dean S. The genetics of keratoconus. Clin Exp Ophthalmol 2001;29:345-51.

4 Zu LX, Xang HY, Wang YP, Figueroa KP, Rotter J, Pulst SM, Rabinowitz YS Identification of a putative locus for keratoconus on chromosome 21. Am J Hum Genet 1999:65:A31:161.

5 Fullerton J, Paprocki P, Foote S, Mackey DA, Williamson R, Forrest S. Identityby-descent approach to gene localisation in eight individuals affected by keratoconus from north-west Tasmania, Australia. Hum Genet 2002; 1 10:462-70.

6 Tyynismaa H, Sistonen P, Tuupanen S, Tervo T, Dammert A, Latvala T, Alitalo T. A locus for autosomal dominant keratoconus: linkage to 16q22.3-q23.1 in Finnish families. Invest Ophthalmol Vis Sci 2002;43:3160-4.

7 Heon E, Greenberg A, Kopp KK, Rootman D, Vincent AL, Billingsley G, Priston M, Dorval KM, Chow RL, Mclnnes RR, Heathcote G, Westall C, Sutphin JE, Semina E, Bremner R, Stone EM. VSX1: a gene for posterior polymorphous dystrophy and keratoconus. Hum Mol Genet 2002;11:1029-36.

8 Rabinowitz YS. Videokeratographic indices to aid in screening for keratoconus. J Refract Surg 1995; 11:371-9.
9 Cottingham RW Jr, Idury RM, Schaffer AA. Faster sequential genetic linkage computations. Am J Hum Genet 1993;53:252-63.

10 Sobel E, Lange K. Descent graphs in pedigree analysis: applications to haplotyping, location scores, and marker-sharing statistics. Am J Hum Genet 1996;58:1323-37.

11 Benson G. Tandem repeats finder: a program to analyze DNA sequences. Nucleic Acids Res 1999;27:573-80.

12 Redmond KB. The role of heredity in keratoconus. Trans Ophthalmol Soc Aust 1968;27:52-4

13 Mann K, Jander R, Korsching E, Kuhn K, Rauterberg J. The primary structure of a triple-helical domain of collagen type VIII from bovine Descemet's membrane. FEBS Lett 1990;273:168-72.

14 Sawada H, Konomi H, Hirosawa K. Characterization of the collagen in the hexagonal lattice of Descemet's membrane: its relation to type VIII collagen. J Cell Biol 1990; 110:219-27.

15 Biswas S, Munier FL, Yardley J, Hart-Holden N, Perveen R, Cousin P, Sutphin JE, Noble B, Batterbury M, Kielty C, Hackett A, Bonshek R, Ridgway A, McLeod D, Sheffield VC, Stone EM, Schorderet DF, Black GC. Missense mutations in COL8A2, the gene encoding the alpha2 chain of type VIII collagen, cause two forms of corneal endothelial dystrophy. Hum Mol Genet 2001;10:2415-23.

\section{$\mathrm{ECHO}$}

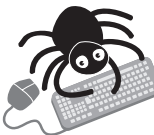

Please visit the Journal of Medical Genetics website [www. jmedgenet. com] for a link to the full text of this article.

\section{Aetiology of colorectal cancer and relevance of monogenic inheritance}

M Ponz de Leon, P Benatti, F Borghi, M Pedroni, A Scarselli, C Di Gregorio, L Losi, A Viel, M Genuardi, G Abbati, G Rossi, M Menigatti, I Lamberti, G Ponti, L Roncucci

Background and aims: Although diet and lifestyle are associated with the development of colorectal malignancies, the only clearly identified aetiological factors in colorectal cancer are inheritance (hereditary non-polyposis colorectal cancer (HNPCC) and familial polyposis), inflammatory bowel diseases, papillomavirus, and acquired immunodeficiency syndrome (AIDS). Our aim was to determine what proportion of colorectal neoplasms could be attributed to these specific factors.

Patients and methods: Data from a colorectal cancer registry were analysed over a 15 year period, during which nearly 2500 cases were recorded. In patients with suspected HNPCC, microsatellite instability and immunohistochemical expression of proteins encoded by the main DNA mismatch repair genes were assessed. In families with unstable neoplasms, constitutional mutations of the mismatch repair genes hMSH2, hMLH1, and hMSH6 were evaluated by single strand conformation polymorphism analysis and sequencing.

Results: Inflammatory bowel diseases, familial polyposis, and AIDS were rare causes of colorectal cancer (three, three, and one case, respectively). Anal squamous carcinoma developed in 27 patients $(1.0 \%)$ and could be attributed to papillomavirus infection. In 58 patients (from 34 families) a clinical diagnosis of HNPCC was established (2.4\%). In total, cases with a known aetiology were 92 (3.7\% of all patients). Microsatellite instability was detected in 15 cancers from HNPCC families, and germline mutations in six families (12 patients, $0.5 \%$ of the total). Families with unstable tumours, with or without mutations, were clinically similar, suggesting the involvement of the mismatch repair system even when mutations were not detected.

Conclusions: The study suggests that the aetiology of colorectal malignancies remains elusive in the large majority of cases. Among specific causes, HNPCC represents the most frequent. However, with a population based approach, constitutional mutations of the main genes involved in HNPCC can be detected in only $20 \%$ of cases.

A Gut 2004;53:115-122. 